\title{
THE RENAL EXCRETION OF CHLORIDE AND WATER IN DIABETES INSIPIDUS
}

\author{
By ROBERT C. HICKEY AND KENDRICK HARE \\ (From the Departments of Surgery and Anatomy, State University of Iowa, Iowa City)
}

(Received for publication October 11, 1943)

The primary purpose of these studies was the development of an objective test for distinguishing a sustained diuresis resulting from excessive and habitual water drinking from the polyuria caused by a defect of the neurohypophysis. It is now well established that the hypothalamicohypophyseal mechanism contributes to control of the renal excretion of water by regulating the release of pituitrin. A technic for testing the functional integrity of this system is based on the demonstration by Hare, Hare, and Phillips (1) that the renal response to the administration of hypertonic saline is consistently different in normal dogs and in dogs with experimental diabetes insipidus. They found that the effect of pituitrin during a saline diuresis could be more clearly revealed by centering attention upon the character of the tubular reabsorbate than upon values in the urine; i.e., upon the concentration of chloride in the water taken from glomerular filtrate and restored to the blood, regardless of tubular regions involved in this process. The relation of chloride concentration in the reabsorbate to that in plasma is defined by the $R / P$ ratio. This ratio changes in the normal $\operatorname{dog}$ throughout the course of a saline or water diuresis. When hypotonic saline is given intravenously or water by mouth, the chloride $\mathrm{R} / \mathrm{P}$ rises rapidly from its basal value of one; but when strongly hypertonic saline is injected, the chloride $\mathrm{R} / \mathrm{P}$ falls progressively. In diabetes insipidus, however, the chloride $\mathrm{R} / \mathrm{P}$ is initially greater than one and during the infusion of hypertonic saline, it usually increases. The addition of pituitrin to the infusion fluid restores the response to normal, but the quantity of hormone required (500 to 1000 milliunits) is at least 100 times that liberated within the same period from the pituitary of a normal dog under basal conditions (2). It is concluded that, in the normal dog, hypertonic saline causes the release of large amounts of pituitrin from the neurohypophysis.
If the neurohypophyseal mechanism in man responds in the same manner, its functional capacity should be evident in the renal response of a patient to the intravenous infusion of hypertonic saline. The observations on patients were made by applying the same procedures used by Hare, Hare, and Phillips (1) with 2 modifications: glomerular filtration, necessary in the calculation of tubular reabsorption, was measured by inulin instead of creatinine clearances, and the quantity of infusion fluid, expressed in relation to body weight, was reduced by more than half. Of secondary interest was the comparison of the renal excretion of salt by normal subjects and by patients with diabetes insipidus. White and Findley (3) reported that salt given by mouth was excreted more slowly than normal by patients with diabetes insipidus, but that pituitrin was not effective in correcting this fault. We (1) failed to find any difference in the renal excretion of salt injected intravenously into normal dogs and those with experimental diabetes insipidus, but since the species and the route of administering the salt were not the same, we extended our observations to man and gave the test dose of salt by mouth and by injection.

\section{PROCEDURES}

Seven consecutive clearance periods of about 15 minutes each were run on all patients. The first 2 periods served as controls; during the next 3 , a saline solution was infused intravenously at $0.25 \mathrm{cc}$. per $\mathrm{kgm}$. per minute. Twenty cc. of a 10 per cent inulin solution in isotonic saline were given intravenously 15 minutes before the beginning of the first period and continued as a sustaining infusion at $\mathbf{0 . 5}$ cc. per minute throughout the experiment. Urines were collected by catheter and complete emptying of the bladder was assured by repeatedly washing the bladder with air at the end of each clearance period. Blood samples were collected before the experiment (for the inulin blank) and at the midpoint of each period. They were drawn under oil without an anticoagulant and centrifuged immediately.

Thirteen experiments of the type described above were done on 5 normal subjects and 3 patients who were routinely taking pitressin tannate in oil to control their urine 
volume. For convenience, the term "polyuric" is used to designate these patients, without regard for the cause of their increased water exchange. Pitressin therapy was discontinued and the urine flow allowed to reach a plateau in the patients before any observations were made. In the studies on the renal excretion of chloride, the data from these infusion experiments were used in addition to those obtained on 3 polyuric and 2 normal subjects given salt by mouth. At first, these latter experiments were done according to the schedule of White and Findley (3), but later were extended to cover 24-hour water and chloride exchange. Under this regimen, the urines were voided and pooled into 12 -hour samples.

Chlorides in urine and serum were determined by the silver nitrate method of Van Slyke and McLean (4) or by the mercurometric titration of Schales and Schales (5). After glucose was removed by fermentation, inulin analyses were done according to Harrison's (6) modification of the diphenylamine method with a Klett-Summerson colorimeter.

\section{CLINICAL MATERIAL}

The case histories of the 3 polyuric patients who received the intravenous saline injections are given below.

L. S. No. 42-5976. This 16-year-old male has had a polyuria for 12 years. He was a premature baby with a birth weight of $1.7 \mathrm{kgm}$. and developed poorly. At 4 years of age, he began to excrete large volumes of urine (almost 6 liters daily) of low specific gravity. Pituitrin nose-drops were used at first to control the polyuria, but were later replaced with pitressin tannate in oil with great success. The urine has been sugar-free on repeated tests and the glucose tolerance test normal. Without pitressin therapy, the daily urine volume is now 8 to 10 liters with a specific gravity of 1.001 to 1.003 . X-ray films of the head show no abnormality. Growth has been subnormal throughout life; at the age of 4 , he weighed $12.5 \mathrm{kgm}$. and was 36 inches high; at 15, he weighed $31 \mathrm{kgm}$. with a height of 55 inches and a skeletal age of 13 according to Todd's Atlas. At the time of this admission, he weighed $40.5 \mathrm{kgm}$.

$M$. $M c C$. No. 39-387. This patient is a 20-year-old male who has Schüller-Christian's syndrome with diabetes insipidus. He has been admitted to the hospital 8 times within the past 5 years. The first admission at the age of 15 was because of a severe weight loss, and on the pediatric service, it was noted that he excreted more urine than normal and that it was of low specific gravity. This polyuria increased in severity and when the patient was 17 he was placed on a regimen of nasal insufflations of posterior pituitary powder. Without therapy, the daily urine volume was 12 to 15 liters. In May, 1940, a diagnosis of Schüller-Christian's disease was made and a lipoid granuloma removed from the right mastoid process. His teeth began to fall out in 1938 and in 1941 complete dentures were obtained. X-ray plates of the head showed no lesions in the region of the pituitary fossa. The patient weighed $52 \mathrm{kgm}$. at the time these experiments were performed. One cc. of pitressin tannate in oil controlled the polyuria for 5 , to 7 days.

$M$. $M$. No. $40-2895$. This patient is a 47 -year-old white housewife who has been receiving pituitrin or pitressin tannate in oil for the past 10 years to control a polyuria and polydipsia which began suddenly in 1933 without any history of preceding illness or trauma. Two months after the onset of her polyuria, her visual fields and the $\mathrm{x}$-ray plates of her head were normal. The Wasserman was negative. The daily urine volume varied from 4 to 9 liters, and when water was withheld, the patient became weak and ill. At this time, the patient was given $1 \mathrm{cc}$. of pituitrin 3 times daily, but for economic reasons, posterior pituitary powder by nasal insufflation was substituted. A week after discharge from the hospital, the patient returned to pituitrin injections. In March, 1940, the patient was put on pitressin tannate in oil, receiving an injection every 12 hours. Her weight on admission, April 16, 1943, was $78 \mathrm{kgm}$.

The normal subjects were free from renal disease and in good health.

\section{RESULTS}

Since these observations are an extension of those made on dogs, the first 3 experiments were done on a normal subject to establish that the human kidney responded like that of the dog to saline solutions of different concentrations. The data from 1 of these experiments, in which 2.5 per cent $\mathrm{NaCl}$ was injected, are given in detail in Table I. The temporal course of the chloride $\mathrm{R} / \mathrm{P}$ of the 3 experiments, graphically shown in Figure 1, is similar to that reported for dogs (1). The elevation of the chloride $R / P$ during the infusion of hypotonic salt solution is attributed

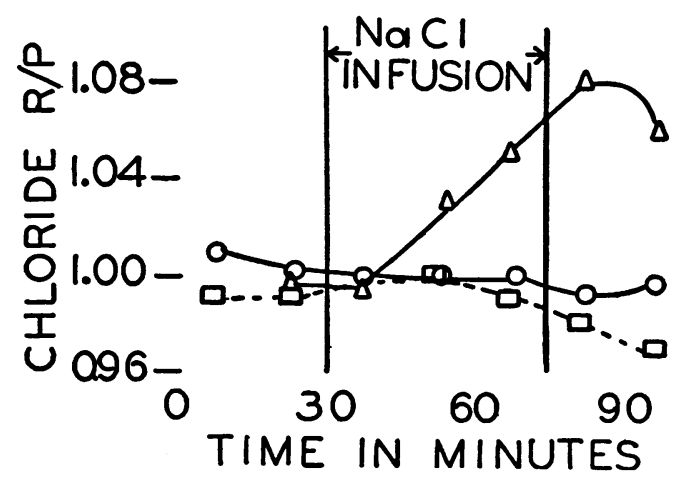

Fig. 1. The Temporal Course of the Chloride R/P in a Normal Subject

Receiving 0.6 per cent (triangles), 0.9 per cent (circles), and 2.5 per cent (squares) $\mathrm{NaCl}$ solution intravenously at the rate of $0.25 \mathrm{cc}$. per $\mathrm{kgm}$. per minute. 
TABLE I

The effects of intravenous injection of 2.5 per cent sodium chloride into normal and polyuric patients

\begin{tabular}{|c|c|c|c|c|c|c|c|c|c|c|c|c|c|}
\hline Subject and period & & Dura- & $\begin{array}{l}\text { Urine } \\
\text { flow }\end{array}$ & $\begin{array}{l}\text { Inulin } \\
\text { clear- } \\
\text { ance }\end{array}$ & $\underset{U / P}{\text { Inulin }}$ & $\begin{array}{l}\text { Plasma } \\
\text { chloride }\end{array}$ & $\begin{array}{l}\text { Chloride } \\
\text { filtered }\end{array}$ & $\begin{array}{l}\text { Chloride } \\
\text { excreted }\end{array}$ & $\begin{array}{c}\text { Chloride } \\
\text { reab- } \\
\text { sorbed }\end{array}$ & $\begin{array}{l}\text { Water } \\
\text { reab- } \\
\text { sorbed }\end{array}$ & $\begin{array}{c}\text { in } \\
\text { tubular } \\
\text { reab- } \\
\text { sorbate }\end{array}$ & $\underset{\mathbf{R} / \mathbf{P}}{\text { Chloride }}$ & $\begin{array}{l}\text { Urine } \\
\text { chloride }\end{array}$ \\
\hline $\begin{array}{l}\text { Normal } \\
\text { K. H. } \\
2.5 \text { per cent sodium } \\
\text { chloride } \\
\text { Weight, } 72 \mathrm{kgm} \text {. }\end{array}$ & $\begin{array}{r}1 \\
2 \\
3 \\
4 \\
5 \\
6 \\
7\end{array}$ & $\begin{array}{l}\text { minutes } \\
16.8 \\
14.0 \\
16.4 \\
15.3 \\
12.5 \\
14.5 \\
15.5\end{array}$ & $\begin{array}{c}c c . \\
\begin{array}{c}c c \\
\text { per } \\
\text { minute }\end{array} \\
2.62 \\
2.34 \\
4.28 \\
6.23 \\
5.62 \\
4.65 \\
4.28\end{array}$ & $\begin{array}{c}c c . \\
\begin{array}{c}c p . \\
\text { per } \\
\text { minute }\end{array} \\
173 \\
182 \\
215 \\
200 \\
191 \\
192 \\
187\end{array}$ & $\begin{array}{l}66 \\
78 \\
51 \\
32 \\
34 \\
41 \\
44\end{array}$ & $\begin{array}{c}\underset{\text { per }}{\operatorname{mgm} .} \\
\text { cent } \\
381 \\
380 \\
385 \\
401 \\
412 \\
410 \\
415\end{array}$ & 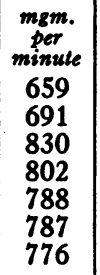 & $\begin{array}{c}\text { mgm. } \\
\text { per } \\
\text { minute } \\
13.9 \\
12.8 \\
21.0 \\
28.4 \\
34.9 \\
33.7 \\
34.9\end{array}$ & $\begin{array}{c}\text { mgm. } \\
\text { per } \\
\text { minute } \\
645 \\
678 \\
809 \\
774 \\
753 \\
753 \\
741\end{array}$ & $\begin{array}{c}c c . \\
\begin{array}{c}c . \\
\text { per } \\
\text { minule }\end{array} \\
171 \\
180 \\
211 \\
194 \\
185 \\
187 \\
183\end{array}$ & $\begin{array}{c}\text { mem. } \\
\text { per } \\
\text { cent } \\
377 \\
377 \\
383 \\
399 \\
407 \\
402 \\
405\end{array}$ & $\begin{array}{l}0.99 \\
0.99 \\
1.00 \\
1.00 \\
0.99 \\
0.98 \\
0.97\end{array}$ & $\begin{array}{l}\text { mgm. } \\
\text { per } \\
\text { cent } \\
532 \\
547 \\
491 \\
456 \\
622 \\
725 \\
816\end{array}$ \\
\hline $\begin{array}{l}\text { Diabetes insipidus } \\
\text { L. S. } \\
2.5 \text { per cent sodium } \\
\text { chloride } \\
\text { Weight; } 40 \mathrm{kgm} \text {. }\end{array}$ & $\begin{array}{r}1 \\
\left\{\begin{array}{l}2 \\
3 \\
4 \\
5\end{array}\right. \\
6\end{array}$ & $\begin{array}{l}14.3 \\
13.7 \\
16.3 \\
17.1 \\
12.5 \\
12.9\end{array}$ & $\begin{array}{r}7.18 \\
6.52 \\
8.53 \\
10.41 \\
11.90 \\
11.30\end{array}$ & $\begin{array}{l}53 \\
53 \\
56 \\
62 \\
64 \\
62\end{array}$ & $\begin{array}{l}7.4 \\
8.1 \\
6.5 \\
5.9 \\
5.4 \\
5.5\end{array}$ & $\begin{array}{l}397 \\
400 \\
404 \\
415 \\
419 \\
421\end{array}$ & $\begin{array}{l}210 \\
212 \\
226 \\
257 \\
267 \\
261\end{array}$ & $\begin{array}{r}4.7 \\
4.7 \\
7.9 \\
13.6 \\
17.9 \\
19.5\end{array}$ & $\begin{array}{l}205 \\
207 \\
218 \\
243 \\
249 \\
241\end{array}$ & $\begin{array}{l}46 \\
46 \\
47 \\
52 \\
52 \\
51\end{array}$ & $\begin{array}{l}445 \\
450 \\
464 \\
468 \\
479 \\
472\end{array}$ & $\begin{array}{l}1.12 \\
1.12 \\
1.15 \\
1.13 \\
1.14 \\
1.12\end{array}$ & $\begin{array}{r}65 \\
72 \\
93 \\
131 \\
150 \\
173\end{array}$ \\
\hline $\begin{array}{l}\text { Diabetes insipidus } \\
\text { M. McC. } \\
2.5 \text { per cent sodium } \\
\text { chloride } \\
\text { Weight, } 52 \mathrm{kgm} \text {. }\end{array}$ & $\left\{\begin{array}{l}1 \\
2 \\
3 \\
4 \\
5\end{array}\right.$ & $\begin{array}{l}16.8 \\
14.1 \\
15.3 \\
14.6 \\
16.5\end{array}$ & $\begin{array}{l}5.28 \\
5.73 \\
6.88 \\
7.52 \\
7.82\end{array}$ & $\begin{array}{l}59 \\
59 \\
59 \\
65 \\
61\end{array}$ & $\begin{array}{c}11 \\
10 \\
8.6 \\
8.6 \\
7.8\end{array}$ & $\begin{array}{l}376 \\
385 \\
400 \\
415 \\
410\end{array}$ & $\begin{array}{l}222 \\
227 \\
236 \\
270 \\
250\end{array}$ & $\begin{array}{l}1.1 \\
1.7 \\
2.5 \\
2.6 \\
2.5\end{array}$ & $\begin{array}{l}221 \\
225 \\
233 \\
267 \\
247\end{array}$ & $\begin{array}{l}54 \\
53 \\
52 \\
57 \\
53\end{array}$ & $\begin{array}{l}409 \\
425 \\
448 \\
468 \\
466\end{array}$ & $\begin{array}{l}1.08 \\
1.10 \\
1.12 \\
1.13 \\
1.14\end{array}$ & $\begin{array}{l}21 \\
30 \\
36 \\
35 \\
32\end{array}$ \\
\hline
\end{tabular}

to a diminution of the amount of pituitrin in the blood; the unchanged chloride $\mathrm{R} / \mathrm{P}$ with isotonic saline indicates little change, if any, in the activity of the neurohypophysis; and the fall of the chloride $R / P$ when hypertonic saline was given signifies the release of pituitrin. In contrast to this, when 2.5 per cent $\mathrm{NaCl}$ solution was given to 2 patients (L. S. and M. McC., Table.I) with diabetes insipidus, the chloride $R / P$, already greatly elevated, increased further (Figure 2). The injection of $0.02 \mathrm{cc}$. (400 milliunits) of pituitrin along with the saline into 1 of these patients (L. S.) sharply depressed the chloride $\mathrm{R} / \mathrm{P}$ (Figure 2) and the renal response simulated that of the normal subject.

The responses of the third polyuric patient (M. M.) were normal (Figure 2) and in sharp contrast to those of the other 2 . Three infusions of 0.9 per cent, 2.5 per cent, and 5 per cent $\mathrm{NaCl}$ were given and, in all experiments, the results indicate a normal control of the excretion of urine. Not only did the response of the patient's kidneys indicate the presence of an antidiuretic substance, but the excretion of the material in her urine was demonstrated. Thirty-minute urine samples were collected immediately before and after the infusion of $250 \mathrm{cc}$. of 5 per cent $\mathrm{NaCl}$ solution and half of each injected intravenously into a dog with diabetes insipidus according to the method of Hare, Hickey, and Hare (7). Each injection was followed by a period of diminished urine flow which was not caused by a reduction of glomerular filtration, but by an increase in the tubular reabsorption of water (Figure 3). The preliminary injection of 1 milliunit of pituitrin was intended to establish the sensitivity of the test animal to the antidiuretic hormone and to provide a response to which subsequent responses could be compared. When the basal urine flow of the test animal remains constant, a high correlation exists between the response and the dose of pituitrin (8), but when the basal flow changes, as in this assay, the responses to successive doses cannot be accurately compared. However, the presence of an antidiuretic substance in the urine of $M$. M. is clearly shown, and, on repetition of the assay on another dog, results practically identical with those shown in Figure 3 were obtained. The significance of the antidiuretic action of this 
patient's urine is enhanced by the observation that urines from 3 other untreated polyuric patients had a diuretic effect when similarly tested. When pituitrin was injected into 1 of these patients, an antidiuretic substance immediately appeared in the urine. This is in exact agreement with the findings of Hare, Hickey, and Hare (7) that the urine from untreated dogs with experimental diabetes insipidus augmented the urine flow of the test animal, while urine collected from the same dogs after the injection of pituitrin produced an antidiuresis.

These results are so nearly identical with those obtained in dogs, both normal and with experimental diabetes insipidus, that the test for neurohypophyseal function in man is considered valid. However, its complexity makes its clinical application difficult, and a simpler indicator of the presence or absence of pituitrin is the concentra-

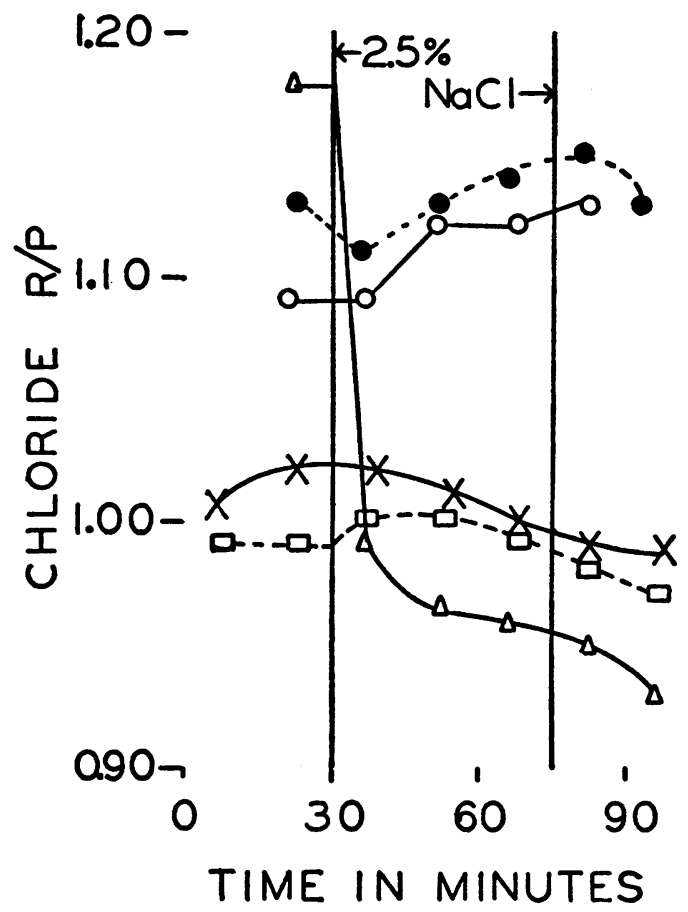

Fig. 2. The Temporal Course of the Chloride $\mathrm{R} / \mathrm{P}$ WHEN 2.5 PER CENT NACL IS INFUSEd at THE RATE of 0.25 CC. PER KGM. PER MINUTE INTO POLYURIC PATIENTS (SOLID CIRCLES, L. S.; OPEN CIRCLES, M. MCC.; CROSSES, M. M.) AND INTO a Normal (SQUares)

The addition of $\mathbf{4 0 0}$ milliunits of pituitrin to the infusion fluid changed the response (triangles) of $L$. S. from that of a patient with diabetes insipidus (solid circles) to one comparable with the normal (squares).

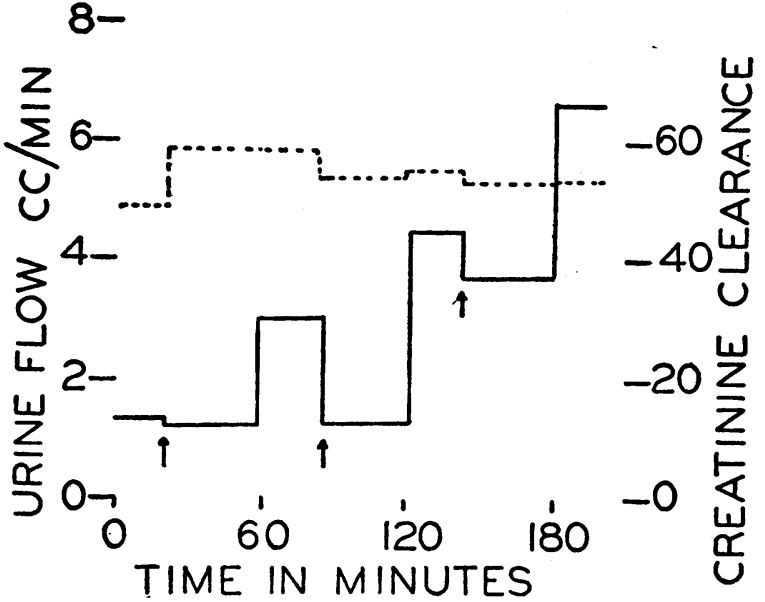

Fig. 3. Demonstration of an Antidiuretic MaTERIAL IN THE URINe OF M. M. Before AND After the InJeCtion of 250 CC. OF 5 PER CENT NACl. SOlution

The solid line indicates the urine flow of the test animal, a dog with diabetes insipidus; the broken line, the rate of glomerular filtration in cc. per minute as determined by creatinine clearances. At the first arrow, 1.0 milliunit of pituitrin was injected; at the second arrow, $45 \mathrm{cc}$. (15-minute specimen) of urine collected immediately before; and at the third arrow, $22 \mathrm{cc}$. of urine (15-minute specimen) collected from M. M. immediately after the salt injection.

tion ratio of chloride (chloride $\mathrm{U} / \mathrm{P}$ ) which can be determined without measuring glomerular filtration. The effect of pituitrin, as indicated by the chloride $U / P$, is illustrated in Figure 4. The low chloride $U / P$ ratios of the 2 patients with diabetes insipidus are contrasted with the sharp elevation that occurs when pituitrin is added to the saline. To show that the infusion of hypertonic saline is effective in releasing pituitrin during a water diuresis, a normal subject was given $20 \mathrm{cc}$. of water per $\mathrm{kgm}$. of body weight during the hour that preceded the infusion of saline. The increase of the chloride $U / P$ (Figure 4) indicates that the hypertonic salt liberates pituitrin in the hydrated as well as in the untreated normal subject.

Another indicator is urine flow, and since it is, of course, easily measured, its use offers a great advantage. Since a very small dose of pituitrin will sharply depress a water diuresis in a normal subject (9), the intravenous injection of hypertonic saline should also interrupt the course of the diuresis, by causing a release of pituitrin from 


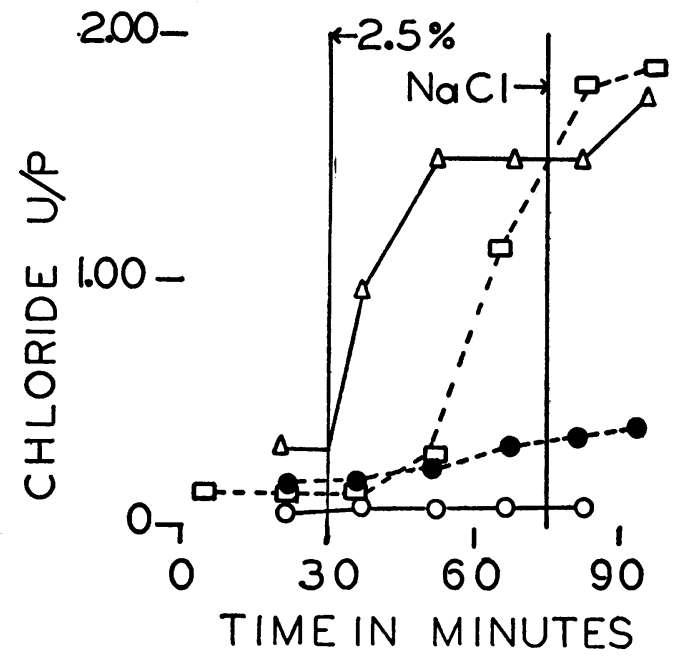

Fig. 4. The Chloride U/P of 2 Untreated PolyURIC Patients, L. S. (SOlid circles) and M. McC. (OPEN Circles), of a Hydrated Normal Subject (squares), and of a Polyuric Patient, L. S., Receiving Pituitrin (triangles) Before, During, and After the Intravenous Infusion of Hypertonic Salt SOlution

the subject's neurohypophysis. This is illustrated in Figure 5. Minute amounts of pituitrin also control the polyuria of a patient with a lesion of the hypothalamico-hypophyseal system, but the injection of hypertonic saline, instead of inhibiting the polyuria, causes a further and striking increase in the urine flow. The greatest difference in the responses is seen in the first period after the infusion is discontinued when the urine flow of the patients with diabetes insipidus is 6 and 9 times as great as that of the normal subject. The use of urine flow as an indicator requires the preliminary hydration of the subject, as an antidiuresis cannot be evaluated if the patient is already oliguric. As a matter of fact, under these circumstances hypertonic saline may be diuretic (See experiment 1, Table I).

When the quantity of chloride excreted after an oral dose was considered, no consistent difference in the response of the 2 groups, normal and polyuric, could be detected, even when the study was followed more than 24 hours after the test dose. Once when a normal patient and one with diabetes insipidus were put on the same high salt diet, the serum chloride of the polyuric patient increased more than the normal and the urinary excretion remained lower. However, this isolated instance of chloride retention after the in- gestion of salt can hardly be considered characteristic of diabetes insipidus since in 7 other experiments, the polyuric and normal subjects excreted the salt at almost identical rates.

Better information for comparing renal excretion of salt is included in the data from the experiments in which the salt was injected intravenously. Four representative cases are shown in Figure 6, in which the chloride excretion, expressed in terms of body weight, is related to time. One of the patients with diabetes insipidus (M. McC.) did excrete chloride at a subnormal rate, while the other (L. S.) responded like the normal subject. The experiment on $\mathrm{L}$. S. was repeated with the addition of pituitrin, and the chloride excretion, which was higher in the control period, continued higher throughout, although the salt injections were identical. The variables in intestinal absorption which may occur after the ingestion of salt are eliminated by injecting the test dose of salt, but even under these conditions, a subnormal excretion of chloride is not a consistent finding in diabetes insipidus.

\section{DISCUSSION}

The idea that the administration of hypertonic saline causes a release of antidiuretic hormone

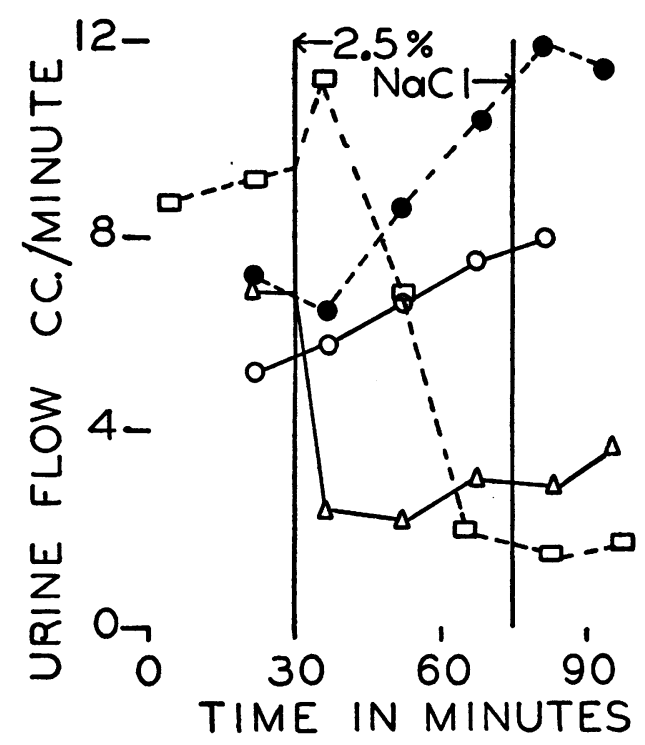

Fig. 5. Urine Flow of Subjects Receiving Hypertonic Saline Injections

Experiments and symbols the same as in Fig. 4. 
from the pituitary seems to have originated with Gilman and Goodman (10) who used this stimulus as an alternative to withholding fluids to create a need for the conservation of water. While the 2 stimuli may act through different mechanisms, both are effective in causing the renal excretion of an antidiuretic substance. Therefore, experiments using either hypertonic saline or dehydration or both will be cited in arraying the evidence that the antidiuretic substance is of pituitary origin. In the experiments of Gilman and Goodman (10), a quantity of 5 per cent $\mathrm{NaCl}$ solution, equal to 5 per cent of the body weight, was given to rats and the urine collected for several hours. The antidiuretic content of the urine, estimated from its inhibitory effect on a water diuresis, was always increased following salt administration to normal animals but was entirely lacking when hypophysectomized rats were similarly treated. Dehydration produced similar results, which have been confirmed, so far as the normal rats are concerned, by Boylston and Ivy (11), and in normal cats by Martin, Herrlich, and Fazekas (12). Ingram, Ladd, and Benbow (13) combined dehydration and intravenous injection of 10 per cent saline to stimulate the renal excretion of an antidiuretic substance in normal cats and obtained results in complete agreement with those of Gilman and Goodman (10). Ingram, Ladd, and Benbow used the less drastic treatment of dehydration alone on cats with experimental diabetes insipidus, but even fatal loss of water by these animals was not attended by the excretion of a detectable amount of antidiuretic material. Walker (14) has strongly protested the pituitary origin of this antidiuretic material since he found it in undiminished amounts in hypophysectomized animals. His argument seems less forceful when one considers that his hypophysectomized animals did not have a polyuria and probably retained a remnant of neurohypophysis, for Heinbecker and White (15) have shown that when all the gland is excised a permanent diabetes insipidus is established.

In all the foregoing experiments, the antidiuretic material was recovered by dialysing the urine through collodion membranes. In order to avoid this complication, Hare, Hickey, and Hare (7) collected the urine by catheter and im-

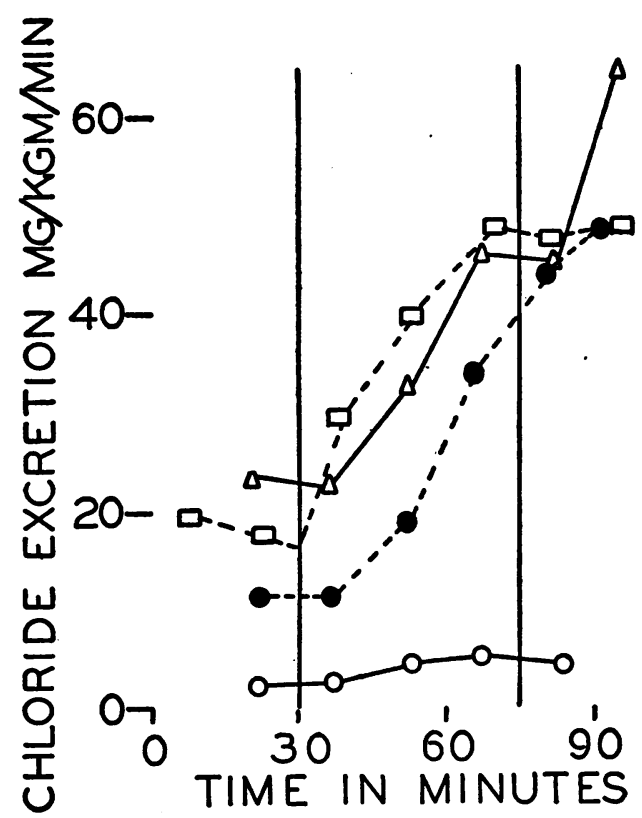

Fig. 6. The Renal Excretion of Chloride by Normal and Polyuric Patients, With and Without Pituitrin

Untreated polyuric patients, L. S. (solid circles) and M. McC. (open circles); polyuric patients, L. S., receiving pituitrin (triangles); normal subject, K. H. (squares). The vertical lines indicate the beginning and end of the infusion of 2.5 per cent $\mathrm{NaCl}$ at 0.25 cc. per $\mathrm{kgm}$. per minute.

mediately injected it intravenously into dogs with diabetes insipidus, that developed an antidiuresis in response to as little as 0.1 milliunit of pituitrin. By this method, it has been found that withholding drinking water (7) or the injection of hypertonic $\mathrm{NaCl}$ or $\mathrm{Na}_{2} \mathrm{SO}_{4}$ solutions (16) caused normal dogs to excrete an antidiuretic substance in the urine. Dehydration of dogs with diabetes insipidus has no such effect, and the absence of the antidiuretic substance from the urine was correlated with its absence from the pituitary by killing the donor and assaying the atrophic pars nervosa of the pituitary and its attachment to the hypothalamus (7).

The validity of the test proposed in this paper is only partly dependent upon the pituitary origin of the urinary antidiuretic substance. It is mainly supported by the fact that the difference in the renal response to the infusion of hypertonic saline into normal dogs and into dogs without a neurohypophysis is abolished by large doses of 
pituitrin (1). Whether part of the pituitrin liberated by the neurohypophysis is excreted in the urine or not, is not essential to the thesis that hypertonic saline is an effective agent for releasing the hormone.

These limited observations on patients, considered alone, scarcely provide the basis for a differential diagnostic test for diabetes insipidus of pituitary origin, but since they confirm findings on normal and polyuric dogs, on which more than 100 similar experiments have been performed, the evidence for the validity of the test is substantial. The one polyuric patient who gave evidence by this test of having an adequate endogenous source of antidiuretic material differed from the others in another respect. While she had the mildest polyuria, she received 8 to 14 times as much pitressin tannate in oil as either of the others. After it was demonstrated that she excreted an antidiuretic substance in her urine and that her responses to infusions of hypertonic saline were normal, she was persuaded to discontinue pitressin therapy for an observation period of 10 days. She developed no polyuria in that time. Three months after leaving the hospital, she reports that her water exchange has remained normal although she has received no treatment since her discharge. It is believed that her polyuria did not originate in a pituitary lesion but was the result of a polydipsia.

In the performance of the test, the subject, whether normal or polyuric, should be given 20 cc. of water per $\mathrm{kgm}$. of body weight during the hour preceding the infusion of 2.5 per cent $\mathrm{NaCl}$ at $0.25 \mathrm{cc}$. per $\mathrm{kgm}$. per minute for a 45 -minute period. Measured collections at 15-minute intervals, preferably by catheter, before, during, and after the salt injection, provide all the necessary information for a differential diagnosis between a polyuria of pituitary origin and the diuresis that results from ingestion of large amounts of water. It is essential that the diuresis be well established, and that the water drinking be continued until the saline injection is begun, to be certain that any decrease in urine flow is not merely the normal decline of the water diuresis. A marked antidiuresis under these conditions indicates the release of pituitrin. This is very similar to the procedure of Gilman and Goodman and differs only in that instead of col- lecting that portion of the antidiuretic substance excreted in the urine and demonstrating its potency by injecting it into a second animal with a water diuresis, the antidiuretic substance liberated into the blood of the subject is detected by its direct action on his own kidneys to suppress a water diuresis.

The difference in the response of patients with diabetes insipidus and normal subjects, as measured by the changes in the chloride $R / P$, in the chloride $U / P$, or in the rate of urine flow, is abolished by replacement therapy with pituitrin. Since the differences in the renal excretion of chloride, described by White and Findley (3), and confirmed by us in 2 of 4 cases, are not corrected by pituitrin, it is improbable that a subnormal rate of urinary excretion of chloride is the fundamental fault in diabetes insipidus. The absence of pituitrin from the circulation seems to be the primary deficiency and the cause of its absence, whether hydration by water drinking or a lesion affecting the neurohypophysis, can be determined by the injection of hypertonic saline.

\section{SUMMARY}

The liberation of the antidiuretic hormone from the neurohypophysis in response to the injection of hypertonic $\mathrm{NaCl}$ provides a means for testing the functional capacity of the gland. The inhibition by salt injection of a pre-existing water diuresis is good evidence that the hypothalamico-hypophyseal system is in good order; a continuation or an increase of the high rate of urine flow suggests that the polyuria is of pituitary origin.

The authors take this opportunity for expressing their thanks to the Departments of Pediatrics and Medicine, for without their cooperation, these experiments could not have been performed.

\section{BIBLIOGRAPHY}

1. Hare, R. S., Hare, K., and Phillips, D. M., The renal excretion of chloride by the normal and by the diabetes insipidus dog. Am. J. Physiol., 1943, 140, 334.

2. Shannon, J. A., The control of the renal excretion of water. The rate of liberation of the posterior pituitary antidiuretic hormone in the dog. $\mathrm{J}$. Exper. Med., 1942, 76, 387.

3. White, H. L., and Findley, T., Jr., Responses of normal subjects and of patients with diabetes insipidus 
to water and salt ingestion. J. Clin. Invest., 1939, $18,377$.

4. Peters, J. P., and Van Slyke, D. D., Quantitative Clinical Chemistry. Vol. II. Methods. The Williams and Wilkins Company, Baltimore, 1932. First edition.

5. Schales, O., and Schales, S. S., A simple and accurate method for the determination of chloride in biological fluids. J. Biol. Chem., 1941, 140, 879.

6. Harrison, H. E., A modification of the diphenylamine method for determination of inulin. Proc. Soc. Exper. Biol. and Med., 1942, 49, 111.

7. Hare, K., Hickey, R. C., and Hare, R. S., Renal excretion of antidiuretic substance by the dog. Am. J. Physiol., 1941, 134, 240.

8. Hickey, R. C., Hare, K., and Hare, R. S., Some cytological and hormonal changes in the posterior lobe of the rat's pituitary after water deprivation and stalk section. Anat. Rec., 1941, 81, 319.

9. Goodman, L., and Gilman, A., The Pharmacological Basis of Therapeutics. The Macmillan Company, New York, 1941. First edition.
10. Gilman, A., and Goodman, L., The secretory response of the posterior pituitary to the need for water conservation. J. Physiol., 1937, 90, 113.

11. Boylston, G. A., and Ivy, A. C., An antidiuretic substance present in the urine of dehydrated rats. Proc. Soc. Exper. Biol. and Med., 1938, 38, 644.

12. Martin, S. J., Herrlich, H. C., and Fazekas, J. F., Relation between electrolyte imbalance and excretion of an antidiuretic substance in adrenalectomized cats. Am. J. Physiol., 1939, 127, 51.

13. Ingram, W. R., Ladd, L., and Benbow, J. T., The excretion of anti-diuretic substance and its relation to the hypothalamico-hypophyseal system in cats. Am. J. Physiol., 1939, 127, 544.

14. Walker, A. M., Experiments upon the relation between the pituitary gland and water diuresis. Am. J. Physiol., 1939, 127, 519.

15. Heinbecker, P., and White, H. L., Hypothalamicohypophysial system and its relation to water balance in the dog. Am. J. Physiol., 1941, 133, 582.

16. Chambers, G., Bradshaw, J., Hare, K., and Hare, R. S., Unpublished observations. 